\title{
DAYA HASIL GALUR-GALUR PADI SAWAH GENERASI LANJUT PADA KONDISI TERCEKAM KEKERINGAN
}

\author{
Yield Potential of Advance Rice Lines on Drought Stress
}

\author{
Estria F. Pramudyawardani*, Rina H. Wening, dan Untung Susanto \\ Balai Besar Penelitian Tanaman Padi, Jl. Raya 9 Sukamandi-Subang \\ *Alamat Korespondensi: pramudyawardani@gmail.com
}

\begin{abstract}
ABSTRAK
Kekeringan pada lahan sawah merupakan masalah yang kerap kali menjadi ancaman pada budidaya padi. Penggunaan varietas yang tepat dapat mengurangi resiko kehilangan hasil yang terlalu besar. Penelitian ini bertujuan untuk mengetahui keragaan hasil 220 galur padi sawah generasi lanjut di lahan kering dibandingkan dengan lahan optimal. Percobaan dilaksanakan pada musim kemarau di kebun percobaan BB Padi Sukamandi, menggunakan rancangan augmented 5 blok dengan 4 varietas pembanding (INPARI 10, INPARI 13, Situ Bagendit, dan Limboto). Perlakuan lahan optimal sesuai dengan cara budidaya yang disarankan, sedangkan lahan kering hanya diairi hingga 4 minggu setelah tanam. Luas plot yang digunakan $1 \mathrm{~m}$ x $5 \mathrm{~m}$ per galur. Pengamatan dilakukan terhadap umur berbunga $10 \%$ dan $50 \%$ (hss), tinggi tanaman (cm), jumlah anakan dan malai per rumpun, bobot seribu butir (gram), dan hasil per plot (kg) dikonversikan menjadi t/ha GKG. Pengamatan terhadap kondisi air tanah, kelengasan tanah, serta skoring gejala kekeringan ditambahkan untuk lahan kering. Sebanyak 23 galur memperoleh hasil lebih baik dari Situ Bagendit (2,32 t/ha GKG) di lahan optimal dan 17 galur lebih baik dari Limboto (1,05 t/ha GKG) di lahan kering. Galur BP15704b-14 dan A 62-1 (BP10764f-10-2) teridentifikasi tumbuh baik di kedua lahan. Tujuh galur dengan produktivitas setara Limboto mempunyai mekanisme ketahanan terhadap kekeringan. Kondisi kekeringan menurunkan tinggi tanaman, bobot seribu butir, dan hasil.
\end{abstract}

Kata kunci: daya hasil, galur padi, lahan kering, kekeringan

\begin{abstract}
Drought often pose a threat to rice cultivation because water is an essential requirement in rice growth. Drought tolerant varieties are expected to mitigate the risks of drought stress. This study aims to determine the performance of 220 advance lines in the dry land as compared with the optimum land. Experiment conducted at Sukamandi esperimental station during dry season. Experiment was arranged in augmented 5 blocks with 4 check varieties (INPARI 10, INPARI 13, Bagendit, and Limboto). The optimum land treatment irrigated based on the recommended cultivation, while the dry land treatment irrigated until 4 weeks after planting only. The plot area was $1 \mathrm{~m} \times 5 \mathrm{~m}$ per lines. Observations was done for: days to 10\% and 50\% flowering (DAS), plant height (cm), number of tillers and panicles per hill, thousand grain weight $(\mathrm{g})$, and yield per plot $(\mathrm{kg})$ converted to t/ha. Addition observations on dry land treatment was done for groundwater, soil moisture, and scoring drought symptom. The result showed 23 lines had higher yield than Situ Bagendit (2.32 t/ha) in optimum land, while 17 lines had higher yield than Limboto (1.05 t/ha) in dry land. BP15704b-14 and A 62-1 (BP10764f-10-2) was identified had stable yield on both treatment. Seven lines which similar with Limboto productivity was estimated to have resistance mechanisms for drought stress. Drought stress decline plant height, grain weight, and yield.
\end{abstract}

Key words: potential yield, dry land, drought

\section{PENDAHULUAN}

Kekeringan kerap kali menjadi ancaman pada budidaya padi dimana tersedianya air merupakan syarat mutlak berjalannya kegiatan tersebut (Kumar et al., 2012; Ouk et al., 2007; Tsubo et al., 2009; Tuberosa dan Salvi, 2006). Akhir-akhir ini fenomena perubahan cuaca yang tidak menentu sangat merugikan bagi petani padi (Hatfield et al., 2011; Ruminta dan Nurmala 2016). Dampak dari kekeringan semakin meluas bukan hanya di lahan gogo dan tadah hujan, tetapi juga di lahan sawah 
dengan irigasi terbatas (Fischer et al., 2012).

Cekaman kekeringan merupakan istilah untuk menyatakan bahwa tanaman mengalami cekaman karena kekurangan air dari lingkungannya. Harjadi dan Yahya (1988) menyebutkan penyebab terjadinya cekaman kekeringan tersebut yaitu: (1) kekurangan suplai air di daerah perakaran, dan (2) permintaan air yang berlebih oleh daun akibat laju evapotranspirasi yang melebihi laju absobsi air oleh akar tanaman, walaupun keadaan air tanah tersedia cukup. Akibat dari cekaman kekeringan akan mempengaruhi kadar air nisbi pada daun menjadi rendah, laju transpirasi menjadi rendah, penurunan laju asimilasi bersih dan laju pertumbuhan nisbi, pertumbuhan luas daun menjadi sempit terutama pada kekeringan fase vegetatif, serta meningkatnya kadar prolin pada tanaman (Kusmarwiyah et al., 2006).

Hasil penelitian Sukiman et al. (2010) menyebutkan bahwa dampak kekeringan pada fase vegetatif tidak terlalu terlihat pada saat masa vegetatif tanaman akan tetapi berpengaruh saat pertumbuhan generatif tanaman. Cekaman kekeringan pada fase primordia dan pembungaan akan meningkatkan jumlah gabah hampa/malai, bobot gabah hampa/malai dan persentase gabah hampa/malai. Fukai dan Cooper (1995) juga menjelaskan bahwa kekeringan pada tingkat ringan sampai menengah mengurangi pelebaran daun dan fotosintesis sehingga akan menurunkan produksi padi.

Observasi daya hasil galur padi terhadap cekaman kekeringan sangat intensif dilakukan, dengan tujuan menguji dan mendapatkan calon varietas padi baru yang dapat beradaptasi baik di lahan terpapar kekeringan (Acuña et al, 2008; Guan et al., 2010; Gu, Qiu, dan Yang, 2013; Lafitte et al., 2006; Venuprasad et al., 2008; Verulkar et al., 2010; Wu, Guan, dan Shi, 2011), maupun terhadap donor toleran kekeringan (Kumar et al., 2008; Lafitte et al., 2006; Torres et al., 2013). Pengujian terhadap galur calon varietas harus terus dilakukan, untuk mendapatkan calon varietas dengan toleransi kekeringan dan daya hasil yang lebih baik daripada varietas yang sudah berkembang. Penelitian ini bertujuan untuk mengetahui keragaan hasil 220 galur padi sawah di lahan kering dibandingkan dengan lahan optimum. Galur-galur yang memiliki hasil tinggi pada lahan kering diharapkan dapat diuji lebih lanjut untuk dapat dilepas sebagai varietas unggul toleran kekeringan.

\section{METODE PENELITIAN}

Materi yang digunakan adalah 220 galur padi yang telah stabil dengan latar belakang yang beragam. Penelitian dilaksanakan di Kebun Percobaan Sukamandi, Jawa Barat pada musim kemarau. Jarak tanam yang digunakan 
adalah $20 \mathrm{~cm}$ x $20 \mathrm{~cm}$, dan luas pertanaman pada setiap plot adalah $1 \mathrm{~m} \times 5 \mathrm{~m}$. Materi ditanam pada dua perlakuan yaitu perlakuan optimal dan perlakuan kering. Perlakuan optimum diairi secara intermitten (pengairan berselang hingga panen) sedangkan perlakuan $\mathrm{K}$ hanya diairi hingga 4 minggu setelah tanam. Untuk menghindari masuknya air ke petak dengan perlakuan kering, maka sepanjang pematang pada perlakuan tersebut dilapisi dengan plastik berukuran 0,8 $\mathrm{mm}$. Masingmasing set perlakuan mengikuti rancangan augmented (Singh dan Chaudhary, 1979) 5 blok dengan 4 varietas pembanding (INPARI 10, INPARI 13, Situ Bagendit, dan Limboto). INPARI 10 merupakan padi sawah yang cocok diaplikasikan pada lahan tadah hujan, INPARI 13 merupakan padi sawah berumur genjah dan hasil tinggi, Situ Bagendit merupakan padi amfibi yang dapat diaplikasikan pada lahan sawah dan lahan gogo, sedangkan Limboto merupakan padi gogo. INPARI 10, Situ Bagendit dan Limboto merupakan padi yang toleran terhadap kekeringan dan INPARI 13 berumur genjah yang dapat escape dari cekaman kekeringan. Keempat varietas tersebut sesuai dijadikan pembanding dalam percobaan ini.

Pengamatan dilakukan terhadap umur berbunga $10 \%$ dan umur berbunga $50 \%$ (hss), tinggi tanaman (cm), jumlah anakan dan jumlah malai per rumpun, bobot seribu butir (g), dan hasil per plot (kg) yang dikonversikan menjadi t/ha GKG, dengan formula sebagai berikut:

$$
\frac{R 1}{R 2} x H \quad p \quad p \quad x\left(\frac{1-k}{8}\right)
$$

Keterangan:

$\mathrm{R} 1=$ jumlah runpun per ha

$\mathrm{R} 2=$ jumlah rumpun yang dipanen dalam tiap plot

$\mathrm{Ka}=$ kadar air yang dianjurkan untuk penyimpanan gabah (14\%).

Data yang terkumpul dari penelitian ini dianalisis dengan analisis ragam tunggal (untuk masing-masing kondisi lahan) dan analisis ragam gabungan. Perbedaan antar rata-rata galur diuji dengan beda nyata terkecil pada taraf beda nyata 5\% (BNT 5\%). Analisis ragam tunggal bertujuan untuk mengetahui perbedaan pertumbuhan dan perkembangan keempat varietas pembanding di masing-masing kondisi lahan percobaan, sedangkan analisis ragam gabungan bertujuan untuk mengetahui pengaruh kondisi lahan terhadap karakterkarakter yang diamati. Analisis data dilakukan menggunakan perangkat lunak IRRISTAT 5.0 dan SAS 9.0.

Pada lahan kering, selain pengamatan di atas ditambahkan juga pengamatan terhadap kondisi air tanah, kelengasan tanah, serta skoring gejala kekeringan. Pengamatan gejala kekeringan disesuaikan dengan sistem pengamatan standar untuk padi (standard evaluation system for rice/SES) (International Rice Research 
Institute, 2013). Alat pengukur kedalaman air tanah adalah paralon yang diberi lubang dengan diameter $15 \mathrm{~cm}$, panjang $35 \mathrm{~cm}$, dan tebal $2 \mathrm{~mm}$. Panjang dinding alat yang dilubangi $25 \mathrm{~cm}$ dan tidak dilubangi $10 \mathrm{~cm}$ dengan ukuran lubang berdiameter $5 \mathrm{~mm}$. Paralon ditanam dalam tanah pada kedalaman $25 \mathrm{~cm}$, dimana bagian berlubang yang dibenamkan ke dalam tanah. Paralon dipasang di dua titik, sebagai perwakilan penggambaran kondisi air tanah. Pengamatan kelengasan tanah dilakukan menggunakan IIROMETER tabung $15 \mathrm{~cm}$ dan $30 \mathrm{~cm}$. Penggunaan kedua ukuran tersebut disesuaikan dengan kemampuan penetrasi perakaran tanaman padi pada umumnya ke dalam tanah.

\section{HASIL DAN PEMBAHASAN}

\section{Kondisi Lahan Kering}

Kondisi ketersediaan air tanah pada lahan kering mulai diamati sejak pengairan dari sistim irigasi dihentikan (Tabel 1), yaitu pada saat tanaman berumur 56 hari setelah sebar (hss). Tren penambahan ketersediaan air permukaan terjadi pada tahap awal pengamatan, hal ini disebabkan karena penambahan air yang bersumber dari hujan. Pada umur 69 hss lahan kering sudah terindikasi kering, di mana air permukaan sudah tidak tersedia dan tanaman hanya dapat memanfaatkan sumber air dari dalam tanah saja. Penurunan tingkat air tanah terus terjadi dan mencapai batas capaian terdalam paralon $(25 \mathrm{~cm})$ pada saat tanaman berumur 75 hss, sehingga ketersediaan air tanah tidak dapat diamati lagi.

Selain kondisi ketersediaan air tanah, kondisi kelengasan tanah di lahan kering juga perlu diamati. Akar tanaman mempunyai kemampuan yang terbatas dalam menembus tanah, pertumbuhan tanaman padi pada umumnya akan terganggu bila kelengasan tanah telah melebihi -60 kPa (Kato, et al., 2009; Torres et al., 2013). Apabila tanaman masih dapat hidup dan tetap menghasilkan pada kondisi demikian, maka dapat disimpulkan tanaman tersebut mengandung gen toleransi terhadap kekeringan.

Pengamatan kelengasan tanah dilaksanakan setiap dua minggu setelah lahan dikeringkan (Tabel 2). Kondisi kelengasan terus menurun sampai dengan akhir musim tanam. Pada pengamatan ke85 hss kondisi kelengasan pada kedua alat IIROMETER telah melampaui batas toleransi akar padi menembus tanah $(>-60$ $\mathrm{kPa}$ ). Lahan dengan kondisi air tanah $0 \mathrm{~cm}$ dan kelengasan tanah lebih dari $-60 \mathrm{kPa}$ pada fase pembungaan dan pengisian gabah tersebut layak untuk dijadikan lahan pengujian toleransi kekeringan terhadap tanaman padi. 
Tabel 1. Kondisi air permukaan dan air tanah di lahan kering

\begin{tabular}{cccc}
\hline No. & Umur tanaman (hss) & \multicolumn{2}{c}{ Tinggi air pada paralon ke- $(\mathrm{cm})$} \\
\cline { 3 - 4 } & & I & II \\
\hline 1 & 56 & +12 & +15 \\
2 & 58 & +17 & +25 \\
3 & 60 & +23 & +19 \\
4 & 61 & +30 & +20 \\
5 & 62 & +27 & +13 \\
6 & 63 & +29 & +7 \\
7 & 64 & +27 & 0 \\
8 & 66 & +20 & -4 \\
9 & 67 & +9 & -3 \\
10 & 68 & +13 & -15 \\
11 & 69 & -10 & -15 \\
12 & 70 & -20 & -20 \\
13 & 71 & -20 & -20 \\
14 & 72 & -20 & -15 \\
15 & 73 & -11 & -13 \\
16 & 75 & -25 & -25 \\
\hline
\end{tabular}

Keterangan: hss $=$ hari setelah sebar, $+=$ diatas permukaan tanah/air permukaan tanah, - = dibawah permukaan tanah/air tanah.

Tabel 2. Data pengamatan kelengasan tanah di lahan kering

\begin{tabular}{ccccc}
\hline No. & Panjang tabung & \multicolumn{3}{c}{ Kelengasan tanah $(\mathrm{kPa})$} \\
\cline { 3 - 5 } & IIROMETER $(\mathrm{cm})$ & $55 \mathrm{hss}$ & 70 hss & 85 hss \\
\hline 1 & 15 & -10 & -35 & -66 \\
2 & 30 & -6 & -15 & -70 \\
\hline
\end{tabular}

Keterangan: hss $=$ hari setelah sebar; $\mathrm{kPa}=$ kilo Pascal.

Pada saat tanaman siap panen terdapat serangan hama lembing batu, yang menyebabkan membusuknya pangkaltanaman dan tanaman menjadi mudah rebah. Serangan lembing batu terjadi pada akhir musim tanam, di mana tanaman sudah melewati masa pematangan gabah, sehingga tidak berpengaruh terhadap perolehan hasil.

\section{Analisis Ragam}

Hasil analisis ragam tunggal di lahan optimum menunjukkan perbedaan yang nyata di antara varietas pembanding untuk karakter umur berbunga 10\%, umur berbunga 50\%, tinggi tanaman, jumlah anakan, dan jumlah malai per rumpun. Hal tersebut menunjukkan bahwa keempat pembanding mempunyai perbedaan karakter agronomis yang jelas dan layak dijadikan sebagai pembanding. Namun demikian, perbedaan karakter-karakter di atas tidak menghasilkan perbedaan perolehan bobot seribu butir dan hasil di lahan optimal, dengan kata lain keempat 
p-ISSN: 1410-0029; e-ISSN2549-6786

Agrin Vol. 21, No. 2, Oktober 2017

varietas pembanding mempunyai

lahan kering, sedangkan karakter hasil kemampuan daya hasil yang sebanding di lahan optimum (Tabel 3).

Data pengamatan di lahan kering menunjukkan hasil yang sedikit berbeda untuk karakter jumlah malai per rumpun dan hasil (Tabel 3). Keragaman karakter jumlah malai per rumpun pada lahan menunjukkan hal yang sebaliknya. Hal tersebut menunjukkan adanya perubahan kemampuan tanaman dalam membentuk malai serta daya hasil di lahan kering, yang mengindikasikan pengaruh kondisi kekeringan terhadap setiap individu tanaman.

optimum lebih tinggi dibandingkan pada

Tabel 3. Hasil analisis ragam tunggal 4 varietas pembanding di lahan optimal dan kering

\begin{tabular}{lcrrr}
\hline Karakter & \multicolumn{2}{c}{ Lahan Optimal } & \multicolumn{2}{c}{ Lahan Kering } \\
\cline { 2 - 5 } & \multicolumn{1}{c}{ KT } & KK $(\%)$ & KT & KK $(\%)$ \\
\hline Umur berbunga 10\% & $34,05^{* *}$ & 2,04 & $44,40^{* *}$ & 2,35 \\
Umur berbunga 50\% & $34,05^{* *}$ & 1,96 & $46,72^{* *}$ & 2,35 \\
Tinggi tanaman & $236,73^{* *}$ & 3,42 & $350,97^{* *}$ & 6,11 \\
Jumlah malai per rumpun & $23,49^{* *}$ & 19,24 & $22,49^{*}$ & 23,76 \\
Jumlah malai per rumpun & $10,34^{* *}$ & 13,38 & $6,64^{\text {ns }}$ & 32,07 \\
Bobot seribu butir & $3,59^{\text {ns }}$ & 39,41 & $3,32^{\text {ns }}$ & 6,10 \\
Hasil & $0,22^{\text {ns }}$ & 26,16 & $0,60^{* *}$ & 40,66 \\
\hline
\end{tabular}

Keterangan: $* *=$ berbeda nyata pada taraf $1 \% ; *=$ berbeda nyata pada taraf $5 \%$; ns $=$ tidak berbeda nyata.

Tabel 4. Data pengamatan 7 karakter utama 220 galur yang diuji di lahan optimal dan kering.

\begin{tabular}{|c|c|c|c|c|c|c|}
\hline \multirow[t]{2}{*}{ Karakter } & \multirow{2}{*}{$\begin{array}{c}\text { Analisis } \\
\text { Ragam } \\
\text { Gabungan }\end{array}$} & \multirow[t]{2}{*}{ Lahan } & \multicolumn{4}{|c|}{ Varietas pembanding } \\
\hline & & & $\begin{array}{c}\text { INPARI } \\
10\end{array}$ & $\begin{array}{c}\text { INPARI } \\
13\end{array}$ & $\begin{array}{c}\text { Situ } \\
\text { Bagendit }\end{array}$ & Limboto \\
\hline \multirow{2}{*}{ Umur berbunga $10 \%$} & \multirow{2}{*}{ ns } & Optimal $^{\mathrm{a}}$ & 75,6 & 69,6 & 73,8 & 71,6 \\
\hline & & Kering ${ }^{a}$ & 76,0 & 70,0 & 74,2 & 70,2 \\
\hline \multirow{2}{*}{ Umur berbunga $50 \%$} & \multirow{2}{*}{ ns } & Optimal $^{\mathrm{a}}$ & 78,6 & 72,6 & 76,8 & 74,6 \\
\hline & & Kering ${ }^{a}$ & 79,2 & 73 & 77,2 & 73,2 \\
\hline \multirow{2}{*}{ Tinggi tanaman } & \multirow{2}{*}{$* *$} & Optimal $^{\mathrm{a}}$ & 84,3 & 82,0 & 79,0 & 94,8 \\
\hline & & Kering $b$ & 64,6 & 69,0 & 63,6 & 81,8 \\
\hline \multirow{2}{*}{ Jumlah anakan } & \multirow{2}{*}{ ns } & Optimal $^{\mathrm{a}}$ & 11,8 & 11,3 & 12,2 & 7,5 \\
\hline & & Kering ${ }^{a}$ & 11,6 & 9,9 & 11,2 & 6,9 \\
\hline \multirow{2}{*}{$\begin{array}{l}\text { Jumlah malai per } \\
\text { rumpun }\end{array}$} & \multirow{2}{*}{ ns } & Optimal $^{\mathrm{a}}$ & 9,0 & 9,5 & 9,0 & 6,3 \\
\hline & & Kering ${ }^{a}$ & 8,7 & 7,5 & 9,5 & 6,9 \\
\hline \multirow{2}{*}{ Bobot seribu butir } & \multirow{2}{*}{$* *$} & Optimal $^{\mathrm{a}}$ & 26,7 & 25,9 & 25,2 & 27,0 \\
\hline & & Kering $b$ & 20,9 & 22,1 & 20,1 & 21,2 \\
\hline \multirow{2}{*}{ Hasil } & \multirow{2}{*}{$* *$} & Optimal $^{\mathrm{a}}$ & 1,88 & 2,25 & 2,32 & 1,99 \\
\hline & & Kering b & 0,26 & 0,86 & 0,57 & 1,05 \\
\hline
\end{tabular}

Keterangan: $* *=$ berbeda nyata pada taraf $1 \%$; ns = tidak berbeda nyata. Huruf berbeda (a dan b) pada baris lahan menunjukkan perbedaan yang nyata berdasarkan uji DMRT $5 \%$. 
Hasil analisis ragam gabungan menunjukkan perbedaan nyata untuk karakter tinggi tanaman, bobot seribu butir, dan hasil (Tabel 4). Hal tersebut mengindikasikan perubahan pola pertumbuhan karakter tinggi tanaman, bobot seribu butir, dan hasil di antara kedua kondisi lahan. Kondisi lahan kering menyebabkan tanaman memendek, bobot gabah menyusut, dan hasil berkurang. Hasil penelitian ini sejalan dengan hasil penelitain Sujinah dan Jamil (2016) yang mempelajari efek kekeringan terhadap pertumbuhan dan perkembangan tanaman padi.

\section{Hasil dan Komponen Hasil}

Varietas Situ Bagendit merupakan pembanding terbaik di lahan optimum, sedangkan Limboto merupakan pembanding terbaik di lahan kering. INPARI 13 merupakan pembanding dengan umur paling genjah baik di lahan optimum maupun kering. Berdasarkan BNT, sebanyak 23 galur di lahan optimum memperoleh hasil nyata lebih tinggi dibandingkan Situ Bagendit (2,32 t/ha GKG), dan dua galur di antaranya mempunyai umur berbunga B10 dan B50 yang nyata lebih genjah daripada INPARI 13 (B10: 69,9 hss; B50: 72,6 hss), yaitu galur BP15646-2b-3 dan BP15704b-14 (Tabel 5). Sedangkan di lahan kering sebanyak 17 galur menunjukkan hasil yang nyata lebih tinggi dari Limboto (1,05 t/ha
GKG). Umur berbunga ke-17 galur tersebut rata-rata lebih genjah atau setara dengan INPARI 13 (Tabel 6).

Bila dicermati lebih lanjut terdapat dua galur sama yang menunjukkan perolehan hasil nyata lebih baik dari varietas pembanding terbaik di kedua lokasi, yaitu galur BP15704b-14 dan galur A 62-1 (BP10764f-10-2). Kedua galur tersebut terbukti mampu beradaptasi dengan baik di lahan optimal maupun di lahan kering, sehingga dapat dikembangkan menjadi galur amfibi, yaitu galur yang dapat ditanam di kondisi basah maupun kering. Salah satu contoh VUB yang merupakan jenis amfibi adalah Silugonggo.

Fase inisiasi bunga dan pengisian gabah merupakan fase kritis tanaman padi terhadap kondisi kekurangan air, yang berpengaruh langsung terhadap daya hasil (Lafitte et al., 2006; Ouk et al., 2007; Pantuwan et al., 2002; Tsubo et al., 2009). Fase berbunga sampai dengan panen pada tanaman padi secara umum memerlukan waktu sekitar 30 hari, sedangkan selisih antara inisiasi (pembentukan) bunga dengan waktu keluarnya bunga adalah 30 hari (Yoshida, 1981). Berdasarkan teori tersebut seluruh galur yang diuji tidak mengalami kekeringan pada saat inisiasi bunga, karena pada saat tanaman berumur 30 hss kondisi air permukaan di lahan kering masih mencukupi (Tabel 1). 
Proses pengisian bulir gabah dimulai setelah terjadinya penyerbukan dan pembuahan (B10). Pada percobaan ini, pengamatan B50 merupakan waktu titik kritis dalam menentukan toleransi tanaman terhadap kondisi kekurangan air. Galurgalur dengan B50 kurang dari 56 hss

Tabel 5. Galur-galur dengan daya hasil nyata lebih tinggi dari cek terbaik (Situ Bagendit) di lahan optimal

\begin{tabular}{|c|c|c|c|c|c|c|c|c|}
\hline \multicolumn{2}{|r|}{ Genotip } & B10 & $\overline{\mathrm{B} 50}$ & TT & $\mathrm{JA}$ & JM & $\mathrm{BG}$ & Hasil \\
\hline 1 & IR 83376-B-B-130-3 & 71,0 & 74,0 & 102,0 & 8,8 & 9,0 & 29,60 & 4,40 \\
\hline 2 & IR83142-B-21-B & 71,0 & 74,0 & 90,2 & 12,0 & 9,3 & 24,83 & 4,61 \\
\hline 3 & IR 83381-B-B-6-1 & 70,0 & 73,0 & 88,4 & 12,0 & 12,7 & 23,74 & 4,79 \\
\hline 4 & BP15646-2b-3 & 57,0 & 60,0 & 70,6 & 16,6 & 10,0 & 24,97 & 3,59 \\
\hline 5 & BP14284e-2-3 & 76,0 & 79,0 & 77,2 & 10,6 & 7,3 & 26,74 & 3,28 \\
\hline 6 & A 35-12 (Erhao) & 75,0 & 78,0 & 90,2 & 9,4 & 10,7 & 21,75 & 3,45 \\
\hline 7 & TB155J-TB-MR-3-1-2 & 70,0 & 73,0 & 105,8 & 7,0 & 7,3 & 27,13 & 3,64 \\
\hline 8 & IR 83377-B-B-105-2 & 71,0 & 75,0 & 92,2 & 10,2 & 8,3 & 25,18 & 3,36 \\
\hline 9 & IR 83364-B-B-95-2 & 71,0 & 74,0 & 82,8 & 9,6 & 8,0 & 21,81 & 3,34 \\
\hline 10 & IR 83388-B-B-8-3 & 70,0 & 73,0 & 78,2 & 11,0 & 11,3 & 22,52 & 3,79 \\
\hline 11 & SMD9-143D-MR-14 & 70,0 & 73,0 & 89,2 & 7,6 & 8,0 & 27,62 & 3,50 \\
\hline 12 & BP11246f-5-3 & 71,0 & 74,0 & 96,6 & 10,2 & 8,0 & 23,70 & 3,70 \\
\hline 13 & BP15704b-14 & 55,0 & 58,0 & 73,0 & 10,2 & 14,3 & 24,97 & 2,70 \\
\hline 14 & IR 83383-B-B-129-1 & 72,0 & 75,0 & 87,2 & 13,0 & 11,0 & 24,37 & 2,20 \\
\hline 15 & IR83142-B-7-B-B & 73,0 & 76,0 & 82,8 & 13,8 & 14,0 & 25,85 & 2,20 \\
\hline 16 & IR87705-83-12-B & 70,0 & 73,0 & 80,0 & 12,0 & 9,7 & 23,89 & 2,30 \\
\hline 17 & PB 8 atau IR8 & 73,0 & 76,0 & 96,4 & 11,2 & 8,0 & 24,55 & 2,50 \\
\hline 18 & IR 83376-B-B-10-4 & 70,0 & 73,0 & 98,6 & 10,6 & 11,3 & 24,74 & 2,50 \\
\hline 19 & A $62-1$ (BP10764f-10-2) & 70,0 & 73,0 & 76,4 & 10,0 & 8,7 & 26,83 & 2,60 \\
\hline 20 & IR83142-B-8-B-B & 70,0 & 73,0 & 80,0 & 11,2 & 9,3 & 27,86 & 2,50 \\
\hline 21 & IR 82589-B-B-138-2 & 68,0 & 71,0 & 94,2 & 9,2 & 10,0 & 24,29 & 2,40 \\
\hline 22 & A $71-2$ (BP11268f-2-1) & 70,0 & 73,0 & 89,2 & 10,0 & 7,0 & 23,43 & 2,90 \\
\hline 23 & IR83141-B-17-B & 70,0 & 73,0 & 85,8 & 11,8 & 9,3 & 25,98 & 3,70 \\
\hline 24 & INPARI 10 & 75,6 & 78,6 & 84,3 & 11,8 & 9,0 & 26,74 & 1,90 \\
\hline 25 & INPARI 13 & 69,6 & 72,6 & 82,0 & 11,3 & 9,5 & 25,89 & 2,30 \\
\hline 26 & Situ Bagendit & 73,8 & 76,8 & 79,0 & 12,2 & 9,0 & 25,17 & 2,30 \\
\hline 27 & Limboto & 71,6 & 74,6 & 94,8 & 7,5 & 6,3 & 27,04 & 2,00 \\
\hline & $\mathrm{KK}(\%)$ & 2,04 & 1,96 & 3,42 & 19,24 & 13,4 & 39,41 & 26,2 \\
\hline & BNT $(5 \%)$ & 2,28 & 2,28 & 4,48 & 3,17 & 1,74 & 15,92 & 0,9 \\
\hline
\end{tabular}

Keterangan: * = menunjukkan berbeda nyata berdasarkan uji lanjut BNT pada taraf $5 \%$. 
Tabel 6. Galur-galur terseleksi dengan daya hasil nyata lebih baik dibanding Limboto di lahan kering

\begin{tabular}{|c|c|c|c|c|c|c|c|c|c|c|}
\hline \multirow[t]{2}{*}{ No } & \multirow[t]{2}{*}{ Galur } & \multirow[t]{2}{*}{$\overline{B 10}$} & \multirow[t]{2}{*}{ B50 } & \multirow[t]{2}{*}{ TT } & \multirow[t]{2}{*}{ JA } & \multirow[t]{2}{*}{ JM } & \multirow[t]{2}{*}{$\mathrm{BG}$} & \multirow[t]{2}{*}{ Hasil } & \multicolumn{2}{|c|}{$\begin{array}{c}\text { Skor } \\
\text { kekeringan }\end{array}$} \\
\hline & & & & & & & & & 81 & 88 \\
\hline 1 & IR 83376-B-B-10-3 & 70,0 & 73,0 & 84,8 & 9,4 & 10,3 & 23,0 & 1,60 & 3,0 & 7,0 \\
\hline 2 & IR87705-44-4-B & 64,0 & 66,0 & 74,2 & 12,0 & 11,3 & 21,5 & 1,52 & 7,0 & SP \\
\hline 3 & BP16734e-6 & 63,0 & 65,0 & 71,8 & 17,2 & 12,7 & 22,2 & 1,89 & 3,0 & 5,0 \\
\hline 4 & BP15648b-8 & 63,0 & 65,0 & 71,4 & 9,8 & 7,3 & 19,9 & 1,52 & 3,0 & SP \\
\hline 5 & BP14262e-2-8 & 64,0 & 66,0 & 65,6 & 12,8 & 12,7 & 18,5 & 1,52 & 5,0 & SP \\
\hline 6 & BP14234e-1-5 & 70,0 & 73,0 & 74,8 & 13,6 & 10,3 & 18,7 & 1,45 & 5,0 & 7,0 \\
\hline 7 & BP15662-4b-4 & 60,0 & 63,0 & 72,8 & 14,6 & 10,3 & 19,8 & 1,50 & 1,0 & SP \\
\hline 8 & IR82589-B-B-84-3 & 68,0 & 71,0 & 87,6 & 9,2 & 7,0 & 20,3 & 1,44 & 5,0 & 9,0 \\
\hline 9 & BP15614b-22 & 63,0 & 66,0 & 72,0 & 12,6 & 8,3 & 20,6 & 1,35 & 7,0 & SP \\
\hline 10 & $\begin{array}{l}\text { A } 68-26 \\
\text { (BP11222f-9-1) }\end{array}$ & 57,0 & 60,0 & 68,8 & 10,8 & 8,3 & 25,7 & 1,71 & 1,0 & SP \\
\hline 11 & IR 82635-B-B-72-2 & 70,0 & 73,0 & 91,2 & 9,6 & 11,3 & 20,3 & 1,78 & 0,0 & 7,0 \\
\hline 12 & BP15630-2b-8 & 55,0 & 59,0 & 74,8 & 13,6 & 9,7 & 22,1 & 2,00 & 7,0 & SP \\
\hline 13 & IR82635-B-B-47-2 & 68,0 & 71,0 & 91,4 & 8,0 & 5,0 & 20,4 & 1,67 & 1,0 & 5,0 \\
\hline 14 & BP15706-1b-14 & 57,0 & 62,0 & 66,2 & 13,6 & 8,0 & 22,4 & 2,56 & 3,0 & 3,0 \\
\hline 15 & BP15704b-14 & 60,0 & 62,0 & 72,2 & 17,2 & 12,7 & 24,3 & 1,78 & 5,0 & SP \\
\hline 16 & IR 83383-B-B-11-4 & 64,0 & 68,0 & 75,6 & 11,0 & 8,7 & 22,7 & 1,90 & 5,0 & 5,0 \\
\hline 17 & $\begin{array}{l}\text { A 62-1 } \\
\text { (BP10764f-10-2) }\end{array}$ & 70,0 & 73,0 & 71,0 & 13,2 & 10,0 & 24,6 & 1,83 & 5,0 & 9,0 \\
\hline 18 & INPARI 10 & 76,0 & 79,2 & 64,6 & 11,6 & 8,7 & 20,9 & 0,26 & 3,8 & 5,4 \\
\hline 19 & INPARI 13 & 70,0 & 73 & 69,0 & 9,9 & 7,5 & 22,1 & 0,86 & 4,4 & 7,8 \\
\hline 20 & Situ Bagendit & 74,2 & 77,2 & 63,6 & 11,2 & 9,5 & 20,1 & 0,57 & 2,6 & 6,2 \\
\hline 21 & Limboto & 70,2 & 73,2 & 81,8 & 6,9 & 6,9 & 21,2 & 1,05 & 2,2 & 6,6 \\
\hline & KK (\%) & 2,35 & 2,35 & 6,11 & 23,8 & 32,1 & 6,1 & 40,66 & & \\
\hline & BNT $(5 \%)$ & 2,62 & 2,74 & 6,56 & 3,63 & 4,0 & 2,0 & 0,43 & & \\
\hline
\end{tabular}

Keterangan: $\mathrm{SP}=$ sudah dipanen, $\mathrm{B} 10=$ umur berbunga $10 \%, \mathrm{~B} 50=$ umur berbunga $50 \%, \mathrm{TT}=$ tinggi tanaman, $\mathrm{JA}=$ jumlah anakan, $\mathrm{JM}=$ jumlah malai per rumpun dan $\mathrm{BG}=$ bobot seribu butir.

Karakter B50 ke-17 galur terseleksi secara umum tidak menunjukkan perbedaan yang nyata antara lahan optimum dan kering, dengan rata-rata B50 67 hss di kedua lahan. Hal tersebut mengindikasikan bahwa ke-17 galur terseleksi masih dapat memanfaatkan ketersediaan air tanah pada fase pengisian gabah. Dapat disimpulkan bahwa galur-galur tersebut mempunyai mekanisme escape terhadap kekeringan berdasarkan karakter B50, karena berumur yang lebih genjah daripada galur lainnya. INPARI 13 (73 hss) dan Limboto (73 hss) merupakan pembanding yang juga mempunyai mekanisme escape berdasarkan karakter umur berbunga. Berdasarkan karakter B50, Situ Bagendit dan INPARI 10 tidak termasuk ke dalam mekanisme toleransi escape. Tujuh galur serupa tercatat memiliki karakter UB50 lebih dari 75 hss 
namun masih mampu memperoleh hasil setara Limboto. Mekanisme toleransi ketujuh galur tersebut masih perlu dipelajari lebih lanjut.

Mekanisme ketahanan terhadap kekeringan pada tanaman padi dapat diamati berdasarkan gejala menggulung daun. Situ Bagendit mengalami kondisi menggulung daun yang lebih cepat dibandingkan INPARI 10 (Tabel 6), hal ini dapat menjelaskan bahwa Situ Bagendit lebih mampu mempertahankan ketersediaan air dalam jaringannya dan melakukan proses pengisian gabah yang lebih baik, sehingga mampu memperoleh hasil yang lebih baik dibandingkan INPARI 10. Toleransi kekeringan berdasarkan gejala menggulung daun Situ Bagendit lebih unggul dibandingkan INPARI 10.

Ketujuh belas galur terseleksi toleran kekeringan mempunyai skor menggulung daun antara 5 sampai dengan 9, kecuali BP1570b-14 yang tidak menunjukkan perubahan bentuk daun (skor 3) sampai dengan panen. Hal tersebut menunjukkan bahwa mekanisme toleransi rata-rata galur terseleksi adalah karena berumur genjah dan mampu menghindari kehilangan air yang berlebih. Seluruh galur ini berpotensi untuk dilanjutkan menjadi varietas unggul baru toleran kekeringan (mekanisme escape) yang lebih baik dari Limboto.

Mekanisme toleransi terhadap kekeringan pada tanaman merupakan karakter yang sangat kompleks dan dipengaruhi oleh banyak karakter morfologis maupun fisiologis (Fukao dan Xiong, 2013). Hasil penelitian ini hanya dapat menjelaskan mekanisme toleransi kekeringan tanaman berdasarkan karakter umur berbunga dan gejala menggulung daun. Studi yang lebih mendalam diperlukan untuk memahami dan mempelajari pola mekanisme toleransi yang lebih tepat terhadap suatu genotipe yang ditengarai toleran terhadap kekeringan, seperti halnya pada kasus galur BP1570b14. Galur BP1570b-14 merupakan salah satu galur dengan daya hasil yang stabil lebih baik dari pembanding di lahan optimum maupun kering, sehingga masih memungkinkan memiliki keunggulan morfologi atau fisiologi lain selain umur genjah, yang menyebabkannya mampu mempertahankan perolehan daya hasil yang stabil lebih tinggi dari pembanding terbaik di lahan kering.

\section{KESIMPULAN}

1. Tujuh belas galur memberikan produksi nyata lebih tinggi dibandingkan Limboto sebagai cek terbaik di lahan kering.

2. Galur BP15704b-14 dan A 62-1 (BP10764f-10-2) dapat beradaptasi dengan baik lahan kering, sehingga layak untuk dikembangkan sebagai varietas padi amfibi. 


\section{UCAPAN TERIMA KASIH}

Penelitian ini didanai dari DIPA BB

Padi tahun 2012. Penulis mengucapkan terima kasih kepada seluruh pihak yang terkait atas penyelenggaraan kegiatan selama penelitian ini berlangsung.

\section{DAFTAR PUSTAKA}

Acuña, T.L.B., H.R. Lafitte, and L.J. Wade. 2008. Genotype x environment interactions for grain yield of upland rice backcross lines in diverse hydrological environments. Field Crops Research, 108(2): 117-25.

Fischer, KS., S. Fukai, A. Kumar, H. Leung and B. Jongdee. 2012. Field phenotyping strategies and breeding for adaptation of rice to drought. Frontiers in Physiology, 3: 1-21.

Fukai, S and M. Cooper. 1995. Development of drought-resistant cultivar using physiomorphological traits in rice. Field Crops Research, 40: 67-86.

Fukao, T. dan L. Xiong. 2013. Genetic mechanisms conferring adaptation to submergence and drought in rice: simple or complex? Current Opinion in Plant Biology, 16(2): 196-204.

Gu, J. F., M. Qiu, dan J. C. Yang. 2013. Enhanced tolerance to drought in transgenic rice plants overexpressing C4 Photosynthesis enzymes. Crop Journal, 1(2): 105-14.

Guan, Y. S., R. Serraj, S.H. Liu, J.L. Xu, J. Ali, W.S. Wang, E. Venus, L.H. Zhu, and Z.K. Li. 2010. Simultaneously improving yield under drought stress and non-stress conditions: a case study of rice (Oryza sativa L.). Journal of Experimental Botany, 61(15): 4145-56.

Hatfield, J.L., K.J. Boote, B.A. Kimball, L.H. Ziska, and R.C. Izaurralde.
2011. Climate impacts on agriculture: implications for crop production. Agronomy Journal, 103(2): 351-70.

International Rice Research Institute. 2013. Standard Evaluation System for Rice. International Rice Research Institute, Phillippine.

Kato, Y., M. Okami, dan K. Katsura. 2009. Yield potential and water use efficiency of aerobic rice (Oryza sativa L.) in Japan. Field Crops Research, 113(3): 328-34.

Kumar, A., J. Bernier, F. Satish, H.R. Lafitte and G.N. Atlin. 2008. Breeding for drought tolerance: direct selection for yield, response to selection and use of drought-tolerant donors in upland and lowlandadapted populations. Field Crops Research, 107(3): 221-31.

Kumar, A., S.B. Verulkar, N.P. Mandal, M. Variar, V.D. Shukla, J.L. Dwivedi, B.L. Singh, O.N. Singh, P. Swain, A.K. Mall, S. Robin, R. Chandrababu, A. Jain, S.M. Haefele, H.P. Piepho, and A. Raman. 2012. High-yielding, drought-tolerant, stable rice genotypes for the shallow rainfed lowland drought-prone ecosystem. Field Crops Research, 133: 37-47.

Kusmarwiyah, R., D. Indradewa, dan Suyadi. 2006. Kajian fisiologis cekaman kekeringan pada jagung manis. Agrosains, 19(3): 225-235.

Lafitte, H. R., Z.K. Li, C.H.M. Vijayakumar, Y.M. Gao, Y. Shi, J.L. $\mathrm{Xu}$, B.Y. Fu, S.B. Yu, A.J. Ali, J. Domingo, R. Maghirang, R. Torres, and D. Mackill. 2006. Improvement of rice drought tolerance through backcross breeding: evaluation of donors and selection in drought nurseries. Field Crops Research, 97(1): 77-86.

Ouk, M., J. Basnayake, M. Tsubo, S. Fukai, K.S. Fischer, S. Kang, S. Men, V. Thun, and M. Cooper. 2007. 
Genotype-by-environment interactions for grain yield associated with water availability at flowering in rainfed lowland rice. Field Crops Research, 101(2): 145-54.

Pantuwan, G., S. Fukai, M. Cooper, S. Rajatasereekul, and J.C. O'Toole. 2002. Yield response of rice (Oryza sativa $\mathrm{L}$.) genotypes to drought under rainfed lowland. Field Crops Research, 73(2-3): 169-180.

Ruminta dan T. Nurmala. 2016. Dampak perubahan pola curah hujan terhadap tanaman pangan lahan tadah hujan di jawa barat Impacts. Jurnal Agrin, 20(2): 155-68.

Singh, R.K. and B.D. Chaudhary. 1979. Biometrical Methods in Quantitave Genetic Analysis. Kalyani Publisher, India.

Sukiman, H., Adiwirman, dan S. Syamsiyah. 2010. Respon tanaman padi gogo (Oryza sativa L.) terhadap stress air dan inokulasi mikoriza. Berita Biologi, 10(2): 249-257.

Sujinah dan A. Jamil. 2016. Mekanisme Respon tanaman padi terhadap cekaman kekeringan dan varietas toleran (mechanism response of rice under drought stress and tolerant varieties). Iptek dan Tanaman Pangan, 11(1): 1-7.

Torres, RO., L. Kenneth, McNally, V.C. Casiana, S. Rachid, and H. Amelia. 2013. Screening of rice genebank germplasm for yield and selection of new drought tolerance donors. Field
Crops Research, 147: 12-22.

Tsubo, M., S. Fukai, J. Basnayake, dan M. Ouk. 2009. Frequency of occurrence of various drought types and its impact on performance of photoperiod-sensitive and insensitive rice genotypes in rainfed lowland conditions in Cambodia. Field Crops Research, 113(3): 287-296.

Tuberosa, R. dan S. Salvi. 2006. Genomicsbased approaches to improve drought tolerance of crops. Trends in Plant Science, 11(8): 405-12.

Venuprasad, R., M.T. Sta Cruz, M. Amante, R. Magbanua, A. Kumar, and G.N. Atlin. 2008. Response to two cycles of divergent selection for grain yield under drought stress in four rice breeding populations. Field Crops Research, 107(3): 232-44.

Verulkar, S.B., N.P. Mandal, J.L. Dwivedi, B.N. Singh, P.K. Sinha, R.N. Mahato, P. Dongre, O.N. Singh, L.K. Bose, P. Swain, S. Robin, R. Chandrababu, S. Senthil, A. Jain, H.E. Shashidhar, S. Hittalmani, C.V. Cruz, T. Paris, and A. Kumar. 2010. Breeding resilient and productive genotypes adapted to drought-prone rainfed ecosystem of India. Field Crops Research, 117(23): 197-208.

Wu, N., Y. Guan, dan Y. Shi. 2011. Effect of water stress on physiological traits and yield in rice backcross lines after anthesis. Energy Procedia, 5: 255-60.

Yoshida, S. 1981. Fundamentals of Rice Crops Science. IRRI, Phillippine. 